\title{
PERSOALAN HUKUM PEREMPUAN REMBANG AKIBAT PRAKTEK NIKAH SIRRI
}

\author{
Khoirul Hidayah \\ Fakultas Syari'ah UIN Maulana Malik Ibrahim Malang \\ Email: Khoirul.hidayah@yahoo.co.id
}

\begin{abstract}
Abstrak
Economics factor motivates Rembang (Pasuruan) women to practice unregistered marriage. Their positions within the marriage causes law problem directing them to poverty. Having no birth certificate registration and no economic warranty in divorce are among law problems facing by the women. Some efforts can be taken by local government are through preventif and repressive efforts. Preventive effort is law empowermnent about marriage, divorce and domestic violence. For repressive effort, the gaverment may implement alternative law solution which is gender sensitive in form of defining the marriage formally (istbat nikah) and registering the marriage in office of religious affairs proactively in cooperation with local officials (village and district).

Faktor ekonomi telah mendorong perempuan di daerah Rembang Pasuruan melakukan praktek nikah sirri. Posisi perempuan Rembang yang dilemahkan sebagai perempuan simpanan dalam praktek nikah sirri menjadikan perempuan menghadapi persoalan hukum yang dapat mengakibatkan kemiskinan. Beberapa persoalan hukum yang dihadapi perempuan Rembang akibat praktek nikah sirri adalah persoalan pengakuan anak melalui akte kelahiran, nafkah anak jika terjadi perceraian dan kekerasan dalam rumah tangga. Upaya penyelesaian yang dapat dilakukan pemerintah daerah dan jajaran pemerintahan yang terkait ada dua yaitu upaya preventif dan upaya represif. Upaya preventif adalah dalam bentuk pemberdayaan hukum tentang perkawinan, perceraian, dan kekerasan dalam rumah tangga. Upaya represif dapat dilakukan dengan upaya penyelesaian hukum alternatif yang sensitif gender yaitu dalam bentuk istbat nikah (penetapan nikah) atau pencatatan nikah oleh KUA secara proaktif melalui kerjasama aparat setempat (desa dan kecamatan).
\end{abstract}

Kata Kunci: Persoalan Hukum, Perempuan Rembang, Praktek Nikah Sirri

Rembang merupakan kecamatan di Kabupaten Pasuruan Jawa Timur yang berada di jalur pembangunan Malang-Pasuruan. Posisistrategistersebutmendorong perkembangan ekonomi di Rembang tersebut berkembang pesat. Kemajuan pembangunan tersebut tidak serta merta menjamin pemerataan hasil-hasil pembangunan itu sendiri sebagaimana yang terjadi di Kecamatan Rembang tersebut. Kecamatan Rembang terdiri dari 17 Desa dengan mata pencaharian sebagian besar penduduknya adalah petani yang penghasilannya pas-pasan.

Faktor kondisi ekonomi ini mendorong perempuan di daerah Rembang melakukan praktek nikah sirri. Nikah sirri, sebelumnya merupakan adat bagi masyarakat Rembang dalam membina rumah tangga yang keberadaannya mendapat dukungan dari para tokoh agama setempat. Mereka menyatakan 
bahwa kebolehan nikah sirri didasarkan kepada alasan untuk menghindari adanya zina dan pernikahan tersebut sudah sah apabila dilakukan di hadapan para tokoh agama tersebut. Dengan adanya legitimasi dari para tokoh agama, maka masyarakat Rembang beranggapan bahwa nikah ini dianggap sah.

Dengan terbitnya Undang-Undang Perkawinan No. 1 Tahun 1974 dan diterbitkannya Peraturan Pemerintah No. 9 Tahun 1975 yang mewajibkan pendaftaran nikah di Kantor Urusan Agama (KUA), tidak serta merta menghapuskan kebiasaan praktek nikah sirri tersebut. Kebiasaan nikah sirri masih tetap dilaksanakan di mana mereka melakukan nikah sirri di hadapan para tokoh agama setempat terlebih dahulu, kemudian melakukan dan mencatatkan pernikahan mereka di KUA.

Rembang merupakan daerah yang secara ekonomi tertinggal dengan tingkat perceraiannya yang relatif tinggi. Karena berbagai alasan, kebanyakan perceraian tidak dilakukan secara resmi di hadapan Pengadilan Agama yang salah satunya adalah mahalnya biaya perceraian yang harus dikeluarkan. Perceraian yang "liar" ini mengakibatkan sulitnya mendapatkan data kuantitatif tingkat perceraian di wilayah Rembang dari Pengadilan Agama setempat.

Posisi perempuan akibat praktek nikah sirri menjadikannya menjadi pihak yang paling menderita karena diperlakukan sangat tidak manusiawi dan tidak adil. Mereka dinikahi dan apabila tidak ada kecocokan di antara mereka, dia ditinggalkan begitu saja. Praktek nikah sirri, pada gilirannya juga berakibat bertambahnya jumlah janda dan anak-anak terlantar secara ekonomi, psikologis maupun status hukum mereka. Para perempuan janda tersebut juga harus memikul tanggung jawab untuk meneruskan kehidupan mereka bersama anakanaknya. Mereka mengambil peran sebagai single parent dalam menjalankan kehidupan mereka, baik secara ekonomi, pendidikan dan sosial.
Berdasarkan pengalaman tersebut, maka para perempuan di wilayah Rembang yang akan dinikahi secara sirri, maka mereka mengajukan salah satu syarat perkawinan, yaitu mahar yang senilai dengan modal kerja yang mereka butuhkan. Langkah ini mereka ambil agar jika suatu saat ditinggalkan suami, mereka masih mampu bertahan hidup. Cara ini pada akhirnya dipandang sebagai cara yang bisa memberikan solusi atas persoalan yang mereka hadapi ketika mereka ditinggalkan oleh suami mereka.

Fenomena pematokan mahar atau mas kawin dengan nilai tertentu mulai dilembagakan. Pelembagaan mahar ini memiliki konsekwensi bahwa para perempuan atau isteri setelah mendapat mas kawin mereka tidak akan menuntut hal-hal yang lain sebagai hak istri pada umumnya, karena kehidupannya secara ekonomi telah dianggap cukup dengan terpenuhinya mahar dengan nilai tertentu sebagaimana yang diinginkannya. Sementara bagi laki-laki yang melakukan nikah sirri dengan perempuan di wilayah Rembang ini cukup dijamin kerahasiaan nikah sirrinya dan diberi kebebasan jika suatu saat meninggalkan isterinya.

Lembaga ini semakin lama semakin kuat dan meluas, sehingga kemudian dimanfaatkan oleh masyarakat setempat untuk mendapat keuntungan dari praktek tersebut. Jaringan untuk melakukan pernikahan sirri tersusun rapi mulai dari makelar dan "tokoh agama" yang menikahkan. Pelembagaan nikah sirri dan kuantitas mahar ini berakibat semakin rendahnya status perempuan. Mereka, selain dieksploitasi secara seksual juga dieksploitasi secara ekonomi oleh masyarakat setempat. Praktek nikah ini telah menjadi komoditas dan sumber ekonomi bagi masyarakat setempat, bahkan para perempuan juga menyukai praktek seperti ini karena bisa menghasilkan uang. Semula praktek ini hanya dilakukan oleh perempuan tertentu saja, kemudian hampir semua perempuan yang menjanda dan tidak mampu secara ekonomi melakukan praktek nikah sirri.

\section{Created with \\ (n) nitro ${ }^{\text {PDF }}$}


Praktek nikah sirri ini telah berjalan puluhan tahun di wilayah Rembang dan memiliki akibat yang tidak sederhana. Salah satu akibat yang dibahas dalam tulisan ini adalah akibat-akibat yang bersentuhan dengan permasalahan hukum dari praktek nikah sirri. Oleh karena itu tujuan penelitian ini adalah: a) untuk mengetahui validitas formal dan materiil nikah sirri menurut perundang-undangan di Indonesia, b) untuk mengetahui permasalahan-permasalahan hukum yang dihadapi oleh perempuan Rembang akibat praktek nikah sirri, c) tawaran solutif atas praktek nikah sirri dan akibatnya yang sensitif gender.

Tulisan ini merupakan hasil penelitian yang dilakukan di enam desa yang berada di Kecamatan Rembang, yaitu: Tampung, Pajajaran, Pekoren, Kalisat, Rembang, dan Geneng Waru. Data yang diperoleh melalui kuesioner dan interview bebas akan dianalisis dengan menggunakan metode deskriptif kualitatif yakni dengan melakukan klasifikasi, identifikasi dan menjelaskan hubungan-hubungan antara data dengan teori legal sistem, teori kesadaran hukum dan teori feminisme liberal.

Istilah nikah sirri berasal dari bahasa Arab dan dalam kamus bahasa Arab kata sirri berasal dari kata sirra, isrâr, berarti rahasia sembunyi-sembunyi, samar (tidak terang). Nikah sirri dapat diartikan sebagai nikah yang dilakukan dengan sembunyisembunyi atau dilakukan secara rahasia. Pernikahan dengan cara ini sebagian besar dilakukan masyarakat pemeluk agama Islam, dan pengukuhannya hanya oleh modin atau tokoh agama.

Nikah sirri menurut pandangan masyarakat Islam adalah nikah yang dilaksanakan sesuai dengan dan memenuhi rukun nikah menurut hukum Islam yaitu adanya calon suami dan calon istri, wali nikah dari pihak wanita, ijab kabul, dan dua orang saksi, akan tetapi pernikahan tersebut tidak didaftarkan atau dilakukan pencatatan oleh pejabat yang berwenang dari KUA.
Menurut Ratna Batara Murni, ${ }^{1}$ nikah sirri berbeda dengan nikah di bawah tangan. Menurutnya yang menjadi ukuran dari nikah sirri dan nikah di bawah tangan adalah apakah nikah yang dilakukan memakai walimahan (pesta) atau tidak. Meskipun sudah memenuhi rukun nikah, dan telah dicatatkan di KUA, tetapi kalau tidak ada walimahan, maka pernikahan tersebut dianggap nikah sirri. Sedangkan perkawinan bawah tangan atau yang dikenal dengan istilah lain seperti kawin sirri atau nikah sirri adalah perkawinan yang dilakukan berdasarkan aturan Agama atau adat istiadat dan tidak dicatatkan di Kantor Pegawai Pencatat Nikah (KUA bagi yang beragama Islam, Kantor Catatan Sipil bagi non-muslim). ${ }^{2}$

Menurut syari'at Islam, tidak ada perbedaan prinsipil antara perkawinan yang melalui pemerintah atau tidak melalui pemerintah. Dalam terminologi figh tidak dijumpai istilah 'nikah sirri atau non sirri'. Apabila perkawinan itu telah memenuhi syarat dan rukun nikah sebagaimana yang diajarkan oleh kitab-kitab fikih, maka pernikahan itu sah menurut Islam. Apakah perkawinan itu dicatat oleh pemerintah atau tidak dicatat, hak dan kewajibannya tetap sama.

Menurut beberapa definisi di atas, maka nikah sirri dapat didefinisikan sebagai nikah yang dilakukan diam-diam atau rahasia, yaitu pernikahan yang dilakukan oleh wali pihak perempuan dengan seorang laki-laki, disaksikan oleh dua orang saksi, hanya memenuhi prosedur keagamaan atau hukum munakahat saja, tidak disaksikan oleh orang banyak, tidak ada publikasi, tidak dilaporkan atau dicatatkan di Kantor Urusan Agama atau Kantor Catatan Sipil, sehingga tidak ada surat-surat resmi atau akta perkawinan/nikah yang otentik yang menyatakan keduanya diikat oleh tali perkawinan.

1 Ratna Batara Murni \& Hindun Anisah, Posisi Perempuan dalam Hukum Islam di Indonesia, (Jakarta: LBH APIK, 2005), h. 76.

2 Ratna Batara Murni \& Hindun Anisah, Posisi., h. 85 reated with 
Sistem hukum Indonesia tidak mengenal istilah kawin sirri atau semacamnya, dan tidak mengatur secara khusus dalam sebuah peraturan. Namun secara sosiologis istilah ini diberikan bagi perkawinan yang tidak dicatatkan dan dianggap dilakukan tanpa memenuhi ketentuan undangundang yang berlaku. Khususnya tentang pencatatan perkawinan yang diatur dalam UU Perkawinan pasal 2 ayat (2).

\section{Metode Penelitian}

Jenis penelitian yang digunakan adalah sosiologis yuridis dengan pendekatan feminis. Penelitian akan dilakukan di 6 desa yang meliputi desa Tampung, Pajaran, Pekoren, Kalisat, Rembang, dan Geneng Waru. Data yang diperoleh melalui kuesioner dan interview bebas akan dianalisis dengan menggunakan metode deskriptif kualitatif yakni dengan melakukan klasifikasi, identifikasi dan menjelaskan hubunganhubungan antara data dengan teori legal sistem, teori kesadaran hukum dan teori feminisme liberal.

\section{Hasil dan Pembahasan}

\section{Validitas formil Nikah Sirri.}

Validitas formil pernikahan adalah keabsahan nikah secara formil menurut peraturan perundang-undangan perkawinan. Pernikahan dianggap sah apabila memenuhi syarat formil yang disebutkan di dalam peraturan perundang-undangan yang berlaku. Berikut ini peraturan yang terkait dengan keabsahan secara formil terjadinya sebuah pernikahan:

Pertama, Undang-Undang No. 1 Tahun 1974 tentang Perkawinan, pasal 2 menyatakan bahwa:(1) Perkawinan adalah sah, apabila dilakukan menurut hukum masing-masing agamanya dan kepercayaannya itu.(2) Tiap-tiap perkawinan dicatat menurut peraturan perundang-undangan yang berlaku. Pasal tersebut menjelaskan bahwa secara formil sebuah pernikahan harus dilakukan menurut agama masing-masing dan harus dilakukan penca- tatan secara administrasi oleh pejabat yang ditunjuk sebagai syarat formil diakuinya pernikahan oleh negara dan mempunyai kekuatan hukum yang mengikat.

Kedua, Undang-undang No. 22 Tahun 1946 jo UU 32/1954 tentang Pencatatan Nikah, Talak dan Rujuk di Seluruh Daerah Luar Jawa dan Madura. Berikut ini pasal yang mengatur tentang pencatatan nikah yaitu: Pasal 1: (1) Nikah jang dilakukan menurut agama Islam, selanjutnya disebut nikah, diawasi oleh pegawai pencatat nikah yang diangkat oleh Menteri Agama atau pegawai yang ditunjuk olehnya. Talak dan rujuk yang dilakukan menurut agama Islam, selanjutnya disebut talak dan rujuk, diberitahukan kepada pegawai pencatat nikah. Pasal 3: (1) Barang siapa jang melakukan akad nikah atau nikah dengan seorang perempuan tidak dibawah pengawasan pegawai yang dimaksudkan pada ayat pasal 1 atau wakilnya, dihukum denda sebanyakbanjaknya R 50,- (Lima puluh rupiah).(2) Barang siapa yang menjalankan pekerjaan tersebut pada ayat (2) pasal 1 dengan tidak ada haknya, dihukum kurungan selamalamanja 3 bulan atau denda sebanyak-banyaknya R 100,- (seratus rupiah). Pasal ini menjelaskan bahwa pencatatan nikah sebagai syarat formil jika tidak dilakukan, maka terdapat sangsi yang diberikan. Negara tidak akan mengakui sebuah pernikahan yang tidak dicatatkan.

Ketiga, Peraturan Pemerintah No.9 Tahun 1975 tentang Pelaksanaan Undang-Undang No. 1 Tahun 1974 tentang Perkawinan yang diatur di dalam pasal 2. Pasal tersebut berbunyi: (1) Pencatatan perkawinan dari mereka yang melangsungkan perkawinannya menurut agama Islam dilakukan oleh Pegawai Pencatat sebagaimana dimaksud dalam Undang-undang Nomor 32 Tahun 1954 tentang Pencatatan Nikah, Talak dan Rujuk.(2)Pencatatan perkawinan dari mereka yang melangsungkan perkawinannya menurut agamanya dan kepercayaannya itu selain agama Islam, dilakukan oleh Pegawai Pencatat perkawinan pada kantor catatan sipipil sebagaimana dimaksud dalam 
berbagai perundang-undangan mengenai pencatatan perkawinan.

Keempat, Kompilasi Hukum Islam (Instruksi Presiden No. 1 Tahun 1991) menjelaskan syarat formil diakuinya sebuah pernikahan oleh negara adalah diatur di dalam beberapa pasal sebagai berikut: Pasal 4 perkawinan adalah sah, apabila dilakukan menurut hukum Islam sesuai dengan pasal 2 ayat (1) Undang-undang No. 1 Tahun 1974 tentang Perkawinan. Pasal 5 (1) Agar terjamin ketertiban perkawinan bagi masyarakat Islam setiap perkawinan harus dicatat. (2) Pencatatan perkawinan tersebut pada ayat (1), dilakukan oleh Pegawai Pencatat Nikah sebagaimana yang diatur dalam Undang-undang No.22 Tahun 1946 jo Undang-undang No. 32 Tahun 1954.Pasal 6(1) Untuk memenuhi ketentuan dalam pasal 5, setiap perkawinan harus dilangsungkan dihadapan dan di bawah pengawasan Pegawai Pencatat Nikah.(2) Perkawinan yang dilakukan di luar pengawasan Pegawai Pencatat Nikah tidak mempunyai kekuatan Hukum. Pasal 7 (1) Perkawinan hanya dapat dibuktikan dengan Akta Nikah yang dibuat oleh Pegawai Pencatat Nikah. (2) Dalam hal perkawinan tidak dapat dibuktikan dengan Akta Nikah, dapat diajukan itsbat nikahnya ke Pengadilan Agama. (3) Itsbât nikah yang dapat diajukan ke Pengadilan Agama terbatas mengenai halhal yang berkenaan dengan : (a) Adanya perkawinan dalam rangka penyelesaian perceraian; (b) Hilangnya Akta Nikah; (c) Adanya beragam tentang sah atau tidaknya salah satu syarat perkawian; (d) Adanya perkawinan yang terjadi sebelum berlakunya Undang-undang No.1 Tahun 1974 dan; (e) Perkawinan yang dilakukan oleh mereka yang tidak mempunyai halangan perkawinan menurut Undang-Undang No.1 Tahun 1974; (4) Yang berhak mengajukan permohonan itsbat nikah ialah suami atau isteri, anak-anak mereka, wali nikah dan pihak yang berkepentingan dengan perkawinan itu. Pencatatan pernikahan menurut KHI dianggap sebagai syarat sahnya perkawinan dapat diakui oleh negara dan mem- punyai kekuatan hukum. Hal ini bertujuan agar tercipta sebuah ketertiban perkawinan bagi masyarakat Indonesia.

Pengaturan perkawinan di atas telah menjelaskan secara jelas bahwa perbuatan nikah sirri tidak memenuhi syarat formil yaitu dicatatkan oleh pejabat yang berwenang (KUA), sehingga dianggap tidak sah menurut hukum positif yang berlaku. Negara tidak mengakui pernikahan sirri dan negara juga tidak melindungi hak pelaku pernikahan jika terjadi persoalan hukum yang merugikan kedua pihak khususnya pihak perempuan.

\section{Validitas Materiil Nikah Sirri}

Validitas materiil pernikahan adalah keabsahan secara materiil menurut peraturan perundang-undangan perkawinan yang berlaku. Untuk mengetahui keabsahan secara materiil, berikut ini peraturan perundang-undangan yang mengatur substansi syarat sahnya nikah; 1) Undang-Undang No. 1 Tahun 1974 tentang Perkawinan, pasal 2 menyatakan bahwa: Perkawinan adalah sah, apabila dilakukan menurut hukum masing-masing agamanya dan kepercayaannya itu. Pasal ini menjelaskan bahwa syarat sahnya nikah bagi pemeluk agama Islam adalah sesuai dengan hukum Islam. 2) Kompilasi Hukum Islam (Instruksi Presiden No. 1 Tahun 1991) menjelaskan syarat formil diakuinya sebuah pernikahan oleh negara adalah diatur di dalam beberapa pasal sebagai berikut: Pasal 4 Perkawinan adalah sah, apabila dilakukan menurut hukum Islam sesuai dengan pasal 2 ayat (1) Undang-undang No. 1 Tahun 1974 tentang Perkawinan. Pasal 1 Untuk melaksanakan perkawinan harus ada : a. Calon Suami; b. Calon Isteri; c. Wali nikah; d. Dua orang saksi dan; e. Ijab dan Qabul. Syarat sahnya nikah menurut KHI di atas secara materiil atau substansi adalah terpenuhinya rukun nikah sebagaimana yang ada di dalam hukum Islam.

Merujuk pada ketentuan peraturan perundang-undangan di atas maka nikah sirri 
yang terjadi dalam praktek di Rembang adalah secara materiil sudah memenuhi syarat sahnya nikah sesuai dengan hukum positif dan hukum Islam yang dianutnya. Pengaturan pencatatan nikah secara normatif telah memberikan perlindungan hukum bagi perempuan, karena dengan dicatatkan, hak-hak perempuan sebagai istri mempunyai kepastian hukum dalam artian bahwa apabila suami tidak memenuhi kewajiban yang menjadi hak perempuan tersebut bisa menuntut pemenuhan hak tersebut ke pengadilan agama.

Realitas yang terjadi di Kecamatan Rembang, pernikahan yang tidak dicatatkan masih banya terjadi, padahal cara pernikahan tersebut tidak menguntungkan bagi perempuan. Bahkan anehnya orang tua pihak perempuan sendiri yang tidak memperbolehkan pernikahan anak perempuannya. Di sisi lain, para suami juga enggan mencatatkan pernikahannya di KUA, karena perbuatannya dalam melakukan praktek nikah sirri dengan perempuan tersebut bertujuan untuk menjadikannya sebagai perempuan atau isteri simpanan. ${ }^{3}$ Dia merasa takut apabila perbuatannya itu diketahui oleh isteri atau keluarganya.

Fenomena nikah sirri di Kecamatan Rembang ini tidak bisa hanya menyalahkan masyarakat Rembang sebagai masyarakat yang tidak taat hukum, tetapi perlu pengkajian secara mendalam substansi peraturan perundang-undangan dan struktur penegakan hukumnya. Substansi peraturan perkawinan yang perlu diperhatikan adalah bahwa pencatatan nikah bukan menjadi syarat sahnya nikah. Penggunaan ketentuan syarat sahnya perkawinan dalam dua jenis hukum yang berbeda yaitu hukum positif (keabsahan formil) dan hukum Islam (keabsahan materiil) mengakibatkan munculnya perbedaan pemahaman bagi masyarakat pemeluk agama Islam. Ketentuan tersebut mengakibatkan masyarakat membenarkan pernikahan sirri karena dianggap sudah memenuhi syarat sahnya nikah sebagaimana diatur di da-

3 Hasil wawancara lam peraturan perundang-undangan. Perubahan syarat sahnya nikah dalam hal ini yaitu dengan mewajibkan pencatatan nikah di dalam Undang-Undang Perkawinan sangat diperlukan demi ketertiban dan kemaslahatan, sehingga tidak ada yang memanfaatkan lembaga perkawinan sebagai pemuas nafsu dengan merugikan kaum perempuan (isteri).

Pada kasus praktek nikah sirri di Rembang, secara struktural diperlukan upaya khusus yang secara aktif dan terus menerus dilakukan pejabat yang berwenang (KUA) untuk melakukan penyuluhan pentingnya pencatatan nikah. Hasil wawancara penulis terhadap pelaku praktek nikah sirri mengenai program sosialisasi pemerintah terhadap Undang-Undang No. 1 Tahun 1974 dan akibat hukum nikah sirri menyatakan bahwa mereka belum pernah mengikuti sosialisasi tersebut. Namun mereka mengetahui bahwa akibat dari nikah sirri adalah merugikan pihak perempuan. Pada tingkat struktur juga, penegakan hukum melalui pemberian sangsi terhadap pelaku nikah sirri tidak pernah diterapkan, sehingga banyak masyarakat Indonesia yang menganggap pencatatan nikah bukan sebuah kewajiban.

Adanya dikotomi hukum yang dipahami masyarakat Muslim mengenai keberlakuan hukum agama dan hukum negara, mengakibatkan masih banyak terjadi nikah sirri di kalangan masyarakat. Jika aspek hukum negara dijadikan pertimbangan dalam melakukan perkawinan maka perkawinan sirri tidak akan terjadi. Kesadaran masyarakat akan pentingnya perkawinan menurut hukum negara perlu ditunjang dengan sosialisasi terus menerus kepada masyarakat mengenai dampak yuridis dan sosiologis dari pernikahan sirri tersebut.

Keadaan ini diperumit dengan dikeluarkannya fatwa Komisi B MUI di Gontor bulan Juni 2006, yang membahas masâ'il waqi'iyyah mu'âshirah (masalah tematik kontemporer) di mana MUI memfatwakan bahwa nikah sirri dianggap sah apabila 
memenuhi syarat-syarat dan rukun nikah, tetapi pernikahan tersebut menjadi haram, jika melahirkan madharat, baik kepada salah satu pihak maupun kedua belah pihak.

Menurut Friedman setiap negara dan setiap himpunan mempunyai suatu budaya hukum ${ }^{4}$ yang khas dan berbeda dengan himpunan yang lain. Statemen ini, tentu saja tidak berarti bahwa semua orang bebas memberikan pemikiran, tetapi hanya pikiran yang disepakati himpunan tersebut yang digunakan. Di sisi lain, dalam suatu masyarakat terdapat beberapa subculture seperti pemeluk agama Islam dan pemeluk agama lain, kelompok si kaya dan si miskin, suku Jawa dan suku-suku lainnya dan lain sebagainya. Pelaku praktek nikah sirri di Rembang adalah masyarakat pemeluk agama Islam di mana mereka mempunyai

4 Ali Akhmad, Keterpurukan Hukum di Indonesia (Bogor: Ghalia Indonesia, 2005), h. 12. hukum sendiri (hukum Islam) yang mengatur masalah perkawinan, selain hukum negara. Masyarakat pemeluk agama Islam ini bagi Friedman disebut subculture yang mempunyai pengaruh kuat di masyarakat. Mereka masih percaya dan yakin bahwa pernikahan menurut agama adalah sah, sehingga dalam pernikahan sirri ini masyarakat memandang pentingnya hukum agama meskipun tidak ada maksud mereka untuk tidak patuh pada hukum negara.

\section{Akibat Hukum Praktek Nikah Sirri bagi Perempuan di Rembang}

Berdasarkan hasil wawancara dan kuesioner di lapangan ada beberapa permasalahan hukum yang dihadapi perempuan Rembang akibat praktek nikah sirri yaitu: a) pengakuan anak, b) nafkah anak jika terjadi perceraian, dan c) kekerasan dalam rumah tangga, sebagaimana yang dipaparkan

Tabel 1: Tabulasi Data Hasil Wawancara dan Questioner

\begin{tabular}{|c|c|c|c|c|}
\hline No. & Isi wawancara/questioner & \multicolumn{3}{|c|}{ Hasil wawancara/questioner } \\
\hline \multirow[b]{2}{*}{1.} & \multirow{2}{*}{ Umur responden } & $<17 \mathrm{Th}$ & $17-25$ & $>25$ \\
\hline & & $8.3 \%$ & $66.7 \%$ & $25.0 \%$ \\
\hline \multirow[b]{2}{*}{2.} & \multirow{2}{*}{ Pekerjaan } & Pengangguran & Buruh tani & Kerajinan \\
\hline & & $30.3 \%$ & $25.0 \%$ & $41.7 \%$ \\
\hline \multirow[b]{2}{*}{3.} & \multirow{2}{*}{ Pendidikan } & SD & SMP & SMU \\
\hline & & $100 \%$ & 0 & 0 \\
\hline \multirow{2}{*}{4.} & \multirow{2}{*}{ Pernah menikah } & 2 kali & 3 kali & > 3 kali \\
\hline & & $3.3 \%$ & $11.7 \%$ & $85.0 \%$ \\
\hline \multirow[b]{2}{*}{5.} & \multirow{2}{*}{$\begin{array}{l}\text { Pernikahan dicatatkan di } \\
\text { KUA }\end{array}$} & \multicolumn{2}{|c|}{ Ya } & Tidak \\
\hline & & \multicolumn{2}{|c|}{$1.7 \%$} & $98.3 \%$ \\
\hline \multirow[b]{2}{*}{6.} & \multirow{2}{*}{ Mengenali calon suami } & \multicolumn{2}{|c|}{ Ya } & Tidak \\
\hline & & \multicolumn{2}{|c|}{$3.3 \%$} & 96.7 \\
\hline \multirow{2}{*}{7.} & \multirow{2}{*}{ Asal suami } & \multicolumn{2}{|c|}{ Lokal desa } & Luar desa/kota \\
\hline & & \multicolumn{2}{|c|}{$3.3 \%$} & 96.7 \\
\hline \multirow{2}{*}{8.} & \multirow{2}{*}{ Punya anak } & \multicolumn{2}{|c|}{ Ya } & Tidak \\
\hline & & \multicolumn{2}{|c|}{$26.7 \%$} & $73.3 \%$ \\
\hline \multirow{2}{*}{9.} & \multirow{2}{*}{$\begin{array}{l}\text { Hak-hak anak selalu } \\
\text { terpenuhi secara layak }\end{array}$} & \multicolumn{2}{|c|}{ Ya } & Tidak \\
\hline & & \multicolumn{2}{|c|}{$10.0 \%$} & $94.0 \%$ \\
\hline \multirow{2}{*}{10.} & Hak-hak istri selalu terpenuhi & & & Tidak \\
\hline & secara layak & & & $81.7 \%$ \\
\hline & Masalah pengakuan status & & & Tidak \\
\hline 11. & anak & & & 96.7 \\
\hline & & & & Tidak \\
\hline 12. & Serıng terjadı KDRI & & & $98.3 \%$ \\
\hline 13 & Ada syarat materi tertentu & & & Tidak \\
\hline 13. & untuk menikah sirri & & & $8.3 \%$ \\
\hline 14 & Selama menikah, kebutu-han & & & Tidak \\
\hline 14. & terpenuhi secara layak & & & $81.7 \%$ \\
\hline 15 & Setelah bercerai, selalu & & & Tidak \\
\hline 15. & mendapat hak sesuai hukum & & & $98.3 \%$ \\
\hline & & Selalu gar & gan & Menikah secara normal \\
\hline 16. & Harapan & & & $91.7 \%$ \\
\hline
\end{tabular}


dari hasil kuesioner dan wawancara pada rentang waktu 1-12 Agustus 2009 kepada 60 orang responden dari enam desa, yaitu: Tampung, Pajaran, Pekoren, Kalisat, Rembang, dan Geneng Waru berikut ini.

Para perempuan pelaku praktek nikah sirri sadar dengan posisinya sebagai perempuan simpanan bahkan sebelum dan ketika akad pernikahan dilangsungkan di mana dia tidak memiliki hak sebagaimana perempuan lazimnya yang melangsungkan pernikahan secara sah dan dicatatkan. Apabila terjadi perceraian, mereka tidak akan menuntut harta gono gini dan apabila suaminya meninggal dunia, mereka tidak akan menuntut hak memperoleh harta warisan dari mantan suaminya, meskipun hak tersebut ada dalam hukum Islam.

Dari aspek legalitas anak juga menjadi persoalan hukum yang pelik di mana dalam akta kelahiran anak, nama bapak si anak dari pernikahan sirri tidak bisa dicantumkan. Anak dianggap hanya mempunyai hubungan hukum dengan Ibu kandungnya, bahkan anak tersebut sulit memperoleh akta kelahiran, karena syarat untuk mengurus akte kelahiran anak adalah dengan melampirkan akte nikah kedua orang tuanya dan kartu keluarga yang tidak dimiliki oleh para pelaku nikah sirri, padahal akte kelahiran sangat dibutuhkan pada saat anak menempuh dan melanjutkan pendidikan sekolah. Apabila dilihat dari hasil kuesioner di atas yang menunjukkan bahwa hampir semua anak hasil praktek nikah sirri belum mempunyai akte kelahiran, maka praktek nikah sirri tersebut sangat merugikan pihak anak, baik dari sisi hukum, akademis, maupun sosial.

Pencatatan kelahiran dan pengakuan sebagai anak merupakan salah satu hak dasar manusia, karena secara substansial, pencatatan kelahiran adalah wujud pengakuan negara atas eksistensi anak dalam rangka melindungi hak anak tersebut. Pencatatan sipil khususnya yang terkait dengan pencatatan kelahiran sangat penting dalam rangka untuk memastikan identitas diri (nama dan kewarganegaraan) sebagai subyek hukum, dan memastikan fungsi dan status keperdataan seseorang terkait dengan peristiwa-peristiwa hukum yang dihadapi individu (mati, lahir, kawin). Pada sistem pencatatan sipil modern, kejadian penting ini tidak sekedar dicatat atau dikumpulkan semata, tapi juga berguna sebagai data yang dapat dimanfaatkan untuk perencanaan suatu negara. Pencatatan sipil ini memiliki tiga fungsi, yaitu untuk standar hukum status seseorang, perlindungan atas hak asasi manusia, dan fungsi statistik.

Mengingat pentingnya akte kelahiran dari kantor catatan sipil ini, maka pencatatan kelahiran untuk anak hasil nikah sirri ini perlu peran aktif pemerintah untuk membuat kebijakan khusus dalam membantu permasalahan yang dihadapi perempuan dan anak hasil nikah sirri. Selain itu, pemerintah dan pihak-pihak terkait perlu mensosialisasikan secara terus menerus dan berkesinambungan kepada para perempuan mengenai bahaya praktek nikah sirri, agar mereka tidak terjerumus dan dijadikan sebagai obyek eksploitasi seksual dan ekonomi oleh pihak-pihak yang tidak bertanggung jawab. Peningkatan pengetahuan untuk para perempuan di Rembang juga perlu digalakkan karena terjerumusnya mereka ke dalam praktek nikah sirri, salah satu faktornya adalah rendahnya tingkat pendidikan perempuan dan ketidaktahuannya mengenai bahaya nikah sirri dan akibatnya terhadap status anak.

Persoalan nafkah anak juga menjadi persoalan hukum yang pelik. Anak hasil dari praktek nikah sirri ini berusaha diasembunyikan oleh ayahnya dan keberadaannya tidak ingin diketahui oleh keluarganya, sehingga nafkah untuk anak tersebut sulit diperoleh, karena harus dilakukan secara hati-hati dan sembunyi-sembunyi. Akibatnya, peran dan tanggung jawab perempuan yang dinikahi secara sirri akan bertambah berat karena harus menanggung sendiri kebutuhan hidup sang anak yang seharusnya menjadi tanggung jawab ayah sebagai kepala rrumah tangga. 
Persoalan kekerasan dalam rumah tangga (KDRT) adalah persoalan hukum yang sering terjadi dalam keluarga yang melakukan praktek nikah sirri. Kekerasan yang sering terjadi adalah dalam bentuk kekerasan non fisik, seperti tidak memberikan nafkah dalam waktu lebih dari satu bulan. Kekerasan fisikjuga terjadi, namun biasanya apabila terjadi kekerasan fisik tersebut, maka penyelesaiannya sering dilakukan dengan perceraian. Perempuan tidak mau menuntut, meskipun sudah ada UndangUndang KDRT yang dapat melindungi hakhak mereka, namun banyak perempuan yang tidak mengetahui keberadaaan undang-undang tersebut. Di sisi lain, polisi tidak mau menerima pengaduan KDRT jika status perkawinan mereka tidak sah menurut hukum negara.

Berdasarkan persoalan-persoalan hukum yang dihadapi oleh perempuan dan anaknya yang melakukan praktek nikah sirri di atas, maka dapat ditarik benang merah bahwa penyebab utamanya adalah lemahnya atau tidak adanya pengetahuan hukum perempuan terhadap peraturan perundang-undangan yang berlaku. Kelemahan ini melahirkan berbagai persoalan hukum, karena persoalan hukum akan muncul jika perbuatan yang dilakukan tidak sesuai dengan peraturan dan perundang-undangan yang berlaku.

Adabeberapahalyang perludiperhatikan dalam kaitannya dengan ketaatan suatu masyarakat terhadap hukum yang berlaku. Soerjono Soekanto mengatakan bahwa indikator-indikator kesadaran hukum suatu masyrakat adalah 5 ;1) Pengetahuan hukum, artinya seseorang mengetahui bahwa perilaku-perilaku tertentu diatur oleh hukum. 2) Pemahaman hukum, artinya seseorang warga masyarakat mempunyai pengetahuan dan pemahaman mengenai aturanaturan tertentu, terutama dari segi isinya. 3) Sikap hukum, artinya seseorang mempunyai kecenderungan untuk mengadakan penilaian tertentu terhadap hukum. 4)

5 Munir Fuady, Sosiologi Hukum Kontemporer (Bandung, Citra Aditya Bakti, 2007), h. 77.
Perilaku hukum, dimana seseorang berperilaku sesuai dengan hukum yang berlaku.

Dengan demikian, apabila seseorang memiliki persepsi yang negatif terhadap suatu hukum, maka ia akan cenderung berperilaku melanggar hukum, dan apabila ia memiliki perepsi yang positif terhadap hukum, maka ia akan cenderung berperilaku mematuhi hukum. Oleh karena itu, dapat ditarik benang merah bahwa persepsi atau sikap hukum seseorang dapat mempengaruhi perilaku hukumnya.

Undang-Undang Perkawinan sudah berlaku 30 tahun lebih sejak diundangkannya pada tahun 1974, sehingga bisa diasumsikan bahwa semua masyarakat mempunyai pengetahuan tentang hukum perkawinan tersebut. Namun realitasnya, asumsi tersebut tidak benar khususnya para perempuan Rembang pelaku nikah sirri, khususnya mengenai akibat hukum pernikahan tersebut. Dari hasil penelitian, sebab-sebab terjadinya praktek nikah sirri tesebut adalah lebih banyak disebabkan karena pertimbangan ekonomi dan sosial daripada pertimbangan hukum. Mereka cenderung lebih taat kepada hukum Islam daripada hukum negara dalam masalah pernikahan tersebut. Mereka beranggapan bahwa menikah menurut hukum agama sudah dianggap sah dan secara sosial diakui dan diterima masyarakat, sehingga mereka tidak merasa perlu untuk mencatatkan dan mendaftarkan pernikahan mereka di KUA. Keengganan mereka untuk mencatatkan pernikahan juga disebabkan pengalaman mereka atau perempuan lain yang mencatatkan pernikahan mereka, namun pencatatan tersebut tidak memiliki implikasi sebagaimana yang mereka harapkan. Mereka tetap tidak mendapatkan hakhaknya, sehingga mereka menganggap bahwa pernikahan yang dicatatkan memiliki implikasi yang sama dengan pernikahan sirri. Penilaian negatif terhadap pencatatan ini turut memperparah keengganan mereka mencatatkan pernikahan dan turut menyuburkan praktek nikah sirri.

\section{Created with \\ (n) nitro $^{\text {PDF }^{\prime}}$ professional}


Pada kasus praktek nikah sirri di Rembang, pihak perempuan berstatus sebagai isteri atau perempuan simpanan. Sebagai isteri simpanan, keberadaannya berusaha disembunyikandarikeluargapihaklaki-laki, sehingga pihak laki-laki tidak menghendaki perkawinannya didaftarkan di KUA, selain sebagai upaya untuk menyembunyikan perempuan simpanannya, juga untuk menghindarkan diri dari tanggung jawab yang lebih besar. Sikap pihak laki-laki yang demikian membuat posisi perempuan menjadi semakin lemah, mulai dari pendidikan dan pengetahuan, eksploitasi ekonomi dan sosial, hingga tidak memiliki hak untuk menuntut suaminya secara hukum, seandainya suami tidak memenuhi kewajiban atau melakukan KDRT.

Praktek nikah sirri di Rembang adalah salah satu bentuk penyalahgunaan hukum perkawinan Islam untuk kepentingan pribadi dengan mengabaikan hukum negara. Pernikahan mempunyai tujuan mulia untuk membentuk keluarga yang bahagia dan bukan hanya untuk kepentingan sesaat. Lembaga perkawinan telah dijadikan alat untuk melegalkan sesuatu yang tidak dibenarkan, dan perempuan dijadikan sebagai korban yang selalu mengalami ketidakadilan.

Dualisme hukum perkawinan telah mengakibatkan pemahaman hukum dan sikap hukum yang berbeda di dalam masyarakat. Hal ini seharusnya segera dilakukan perubahan terhadap Undang-Undang Perkawinan, sehingga Undang-Undang lebih dapat melindungi hak-hak perempuan sebagaimana yang diharapkan.

\section{Penyelesaian Hukum Sensitif Gender}

Pelaku praktek nikah sirri, berdasarkan data hasil quesioner, hampir seluruhnya berpendidikan Sekolah Dasar atau tidak lulus Sekolah Dasar. Hal ini mengindikasikan bahwa faktor pendidikan sangat mempengaruhi pola berpikir dan bagaimana membuat sebuah keputusan. Praktek nikah sirri di Rembang di mana pihak perempuan dieksploitasi secara seksual dan ekonomi menjadikan perem- puan menjadi pihak yang sangat menderita terlebih lagi apabila pasangan nikah sirri bercerai dan meninggalkan anak, maka beban pihak perempuan bertambah sebagai tulang punggung bagi anak-anak mereka yang tidak diakui oleh suaminya. Oleh sebab itu perlu dilakukan upaya pemberdayaan hukum dan ekonomi terhadap perempuan agar mereka sadar dan tidak mau melakukan praktek nikah sirri yang secara turun menurun mereka lakukan.

Persoalan-persoalan hukum yang dihadapi perempuan Rembang adalah persoalan hukum yang tidak bisa hanya dibebankan kepada pihak perempuan sebagai subyek yang dipersalahkan atas perbuatan yang dilakukan bersama oleh pihak laki-laki dan perempuan. Berdasarkan analisis terhadap persoalan hukum perempuan di atas, dapat ditarik benang merah bahwa faktor kemiskinan, rendahnya pendidikan, pengetahuan hukum dan pemahaman hukum yang kurang pihak perempuan dan rendahnya peran pemerintah khususnya pemerintah daerah dalam melakukan pemberdayaan untuk perempuan menjadi faktor utama maraknya praktek nikah sirri di Rembang.

Upaya penyelesaian yang dapat dilakukan pemerintah dan jajaran lembaga pemerintahan terkait seperti Bapemas, KUA, BP4 dan Pengadilan agama terhadap persoalan hukum yang dihadapi pihak perempuan pelaku nikah sirri, menurut pendapat penulis ada, yaitu: upaya preventif dan upaya represif. Pertama, upaya preventif yang dapat dilakukan adalah pemberdayaan hukum dan pemberdayaan ekonomi bagi perempuan pelaku nikah sirri termasuk anak-anak mereka. Pemberdayaan hukum dilakukan dengan mensosialisasikan peraturan-peraturan yang berkenaan dengan perkawinan, perceraian, dan kekerasan dalam rumah tangga. Progam pemberdayaan ini diharapkan para perempuan menyadari bahaya dan resiko yang mungkin terjadi akibat praktek nikah sirri. Sementara, bagi mereka yang telah terlanjur melakukan praktek nikahth sirri, selain diberdayakan 
dalam bidang hukum, mereka perlu diberdayakan secara ekonomi, khususnya mereka yang telah diceraikan suaminya dan memiliki anak, yaitu dengan pemberian pendidikan gratis atau beasiswa bagi anak-anak korban praktek nikah sirri dengan menuntaskan program wajardikdas 9 tahun.

Sebenarnya, program pemberdayaan ekonomi yang sudah dilakukan oleh Bapemas pada tahun 2005-2008 merupakan langkah awal yang positif, namun pada akhir tahun 2008 telah terjadi pengambilalihan bidang pemberdayaan perempuan dari Bapemas oleh Dinas Keluarga Berencana. Pengambilalihan oleh Surat Keputusan Bupati ini mengakibatkan program Bapemas terputus, sementara pejabat baru pada Dinas Keluarga Berencana tidak mengetahui program pemberdayaan ekonomi Bapemas bagi para perempuan di Rembang.

Pada saat penulis melakukan penelitian di lapangan, sejak pengambilalihan program pemberdayaan perempuan pada akhir tahun 2008 hingga sekarang, belum ada program pemberdayaan perempuan yang khusus mengatasi masalah praktek nikah sirri di Rembang. Pengambilalihan bidang pemberdayaan perempuan oleh pemerintah daerah Kabupaten Pasuruan sangat disayangkan oleh Kementerian Pemberdayaan Perempuan, karena dengan pengambilalihan ini, Pasuruan sudah tidak dapat mengakses dana dari pusat untuk pemberdayaan perempuan. ${ }^{6}$

Upaya pemerintah daerah Pasuruan tidak boleh hanya mengharapkan anggaran dari pemerintah pusat, tetapi harus mengalokasikan anggaran pemerintah daerah (APBD) dalam rangka memberdayakan dan memperhatikan nasib perempuan di Rembang, khususnya mereka yang terjerumus dalam praktek nikah sirri. Peningkatan harkat dan martabat perempuan pelaku praktek nikah sirri diperlukan peran pemerintah daerah Pasuruan dengan

6 Disampaikan oleh Narasumber dari Kementerian Pemberdayaan Perempuan pada Acara Pelatihan Manajemen Pengelola P2TP2A oleh Bapemas pada tgl 30-31 Oktober 2008 di Hotel Perdana Pasuruan melakukan pemenuhan terhadap hak-hak dasar mereka sebagai warga Pasuruan. Pemberian akses terhadap modal, pendidikan dan keterampilan terhadap perempuan pelaku praktek nikah sirri sangat membantu perempuan dalam peningkatan kwalitas sumber daya manusia.

Kedua, upaya represif yang perlu dilakukan adalah perlunya penyelesaian hukum alternatif yang sensitif gender yaitu dengan memberikan kemudahan dan membantu mereka dalam melakukan istbât nika (penetapan nikah) atau pencatatan nikah oleh KUA dan pemberian kemudahan untuk memberikan akte kelahiran bagi anak hasil praktek nikah sirri. Itsbât nikah dan pencatatan nikah di KUA ini bertujuan agar perniahan para perempuan pelaku nikah sirri ini diakui oleh negara dan selanjutnya dapat menuntut hak-haknya sebagai isteri. Meskipun istbat nikah karena pernikahan sirri tidak diperkenankan di dalam KHI, namun harus ada kebijakan dari lembaga yang berwenang agar praktek nikah sirri ini tidak berlanjut terus menerus dan menjadi kebiasaan perempuan untuk memenuhi kebutuhan hidupnya serta dapat memutus jaringan eksploitasi perempuan. Kebijakan hakim melalui lembaga pengadilan agama, diharapkan dapat memberikan keputusan yang sensitif gender dan memberikan keadilan bagi perempuan yang memang mempunyai keinginan untuk hidup normal dan diakui status perkawinannya oleh negara.

Selain itu juga lembaga KUA melalui pegawai pencatat nikah perlu lebih proaktif mencatat semua perkawinan sirri perempuan Rembang, sehingga lembaga perkawinan yang suci tidak dimanfaatkan oleh kaum laki-laki sebagai media untuk mencari isteri atau perempuan simpanan sebagai alat pemuas kebutuhan biologis mereka semata. Upaya pencatatan nikah ini perlu dioptimalkan melalui kerjasama dengan kepala desa dan camat setempat dalam mendata para pasangan pelaku nikah sirri. Pencatatan nikah ini diharapkan akan memberikan efek jera kepada para laki-laki agar tidak melakukan perkawinan sirri 
yang sangat merugikan pihak perempuan tersebut.

Sedangkan upaya yang perlu dilakukan untuk mengatasi persoalan hukum terhadap pengakuan anak oleh ibu melalui akte kelahiran adalah dengan memberikan kemudahan administrasi dalam pembuatan akte kelahiran bagi anak hasil pernikahan sirri. Fungsi akte kelahiran sangat penting untuk anak dalam memperoleh hak-hak keperdataanya karena substansi pencatatan kelahiran adalah untuk melindungi hak anak akan pengakuan identitasnya oleh negara. Hak pengakuan anak oleh negara tidak hilang karena status perkawinan orang tuanya. Mengingat, para perempuan Rembang banyak yang tidak mengetahui pentingnya akte kelahiran bagi anak mereka dan tidak mengeahui prosedur pendaftarannya, maka diperlukan peran aktif dari dinas catatan sipil dan instansi terkait untuk melakukan pendataan atas kelahiran anak akibat praktek nikah sirri.

Beberapa upaya hukum di atas diharapkan dapat membantu persoalan hukum perempuan, sehingga dapat memberikan upaya alternatif yang sensitif gender dalam mengatasi permasalahan perempuan akibat praktek nikah sirri. Selain itu juga aga dapat membantu para perempuan dalam menghadapi keterpurukan kemiskinan yang diakibatkan dari persoalan hukum.

\section{DAFTAR PUSTAKA}

Ali akhmad. 2005. Keterpurukan Hukum di Indonesia. Bogor. Ghalia Indonesia.

Munir Fuady 2007. Sosiologi Hukum Kontemporer. Bandung, Citra Aditya Bakti.

Ratna Batara Munti, Hindun Anisah. 2005. Posisi Perempuan Dalam Hukum Islam di Indonesia. Jakarta, LBH-APIK.

Peraturan perundang-undangan

Undang-Undang No. 7 Tahun 1984 tentang Pengesahan Mengenai Konvensi Penghapusan Segala Bentuk Diskriminasi Terhadap Wanita (Convention on the Elimination of All Forms of Di-
Seluruh upaya di atas dapat efektif jika dibarengi dengan kerjasama dengan semua stakeholder yang terkait termasuk tokoh masyarakat seperti para tokoh agama dan partisipasi masyarakat untuk menolak praktek nikah sirri.

\section{Kesimpulan dan Saran}

Persoalan perempuan di Rembang Pasuruan akibat praktek nikah sirri adalah masalah serius yang harus diperhatikan oleh pemerintah kabupaten Pasuruan. Penyelesaian hukum alternatif yang sensitif gender adalah salah satu bentuk penyelesaian persoalan hukum yang dapat membantu perempuan dalam menghadapi kemiskinan. Kerjasama semua pihak mulai masyarakat, pemerintah daerah dan tokoh masyarakat sangat dibutuhkan untuk menyelesaikan persoalan yang dialami perempuan Rembang. Apabila pemerintah daerah tidak mampu melakukan sendiri untuk mengatasi permasalahan tersebut, pemerintah daerah $\mathrm{Pa}$ suruan perlu secara proaktif mengajukan kerjasama dengan pemerintah pusat melalui Kementerian Pemberdayaan Perempuan untuk melakukan pemberdayaan bagi para perempuan agar kesejahteraan mereka dapat tercapai. Selain itu, program pemerintah daerah untuk pemberdayaan perempuan di Rembang perlu dilakukan secara berkesinambungan, sehingga program pemerintah berjalan efektif.
Undang-Undang No. 1 Tahun 1974 tentang Perkawinan

Undang-Undang No. 22 Tahun 1946 jo UU 32/1954 tentang Pencatatan Nikah, Talak dan Rujuk di Seluruh Daerah Luar Jawa dan Madura.

Peraturan Pemerintah No. 9 Tahun 1975 tentang Pelaksanaan Undang-Undang No. 1 Tahun 1974 tentang Perkawinan

Kompilasi Hukum Islam (Instruksi Presiden $\mathrm{N}_{\mathrm{w}} \mathrm{P}_{\mathrm{i}}$ Tahun 1991) 


\section{PEDOMAN TRANSLITERASI}

Pengalihan huruf Arab-Indonesia dalam naskah ini didasarkan atas Surat Keputusan Bersama (SKB) Menteri Agama dan Menteri Pendidikan dan Kebudayaan Republik Indonesia, tanggal 22 Januari 1988, No. 158/1987 dan 0543.b/U/1987, sebagaimana yang tertera dalam buku Pedoman Transliterasi Bahasa Arab (A Guide to Arabic Tranliterastion), INIS Fellow 1992

\section{A. Konsonan}

\begin{tabular}{|c|c|c|c|}
\hline Arab & Latin & Arab & Latin \\
\hline 1 & a & $b$ & th \\
\hline ب & b & b & $\mathrm{zh}$ \\
\hline ت & $\mathrm{t}$ & $\varepsilon$ & ' \\
\hline$ث$ & $\mathrm{~s}$ & $\dot{\varepsilon}$ & gh \\
\hline T & $\mathrm{j}$ & ف & $\mathrm{f}$ \\
\hline$\tau$ & $\mathrm{h}$ & ق & $\mathrm{q}$ \\
\hline$\dot{\tau}$ & $\mathrm{kh}$ & s) & $\mathrm{k}$ \\
\hline 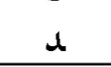 & d & J & 1 \\
\hline j & $\mathrm{dz}$ & 5 & $\mathrm{m}$ \\
\hline$\jmath$ & $\mathrm{r}$ & ن & $\mathrm{n}$ \\
\hline j & $\mathrm{z}$ & 9 & w \\
\hline س & $\mathrm{s}$ & 0 & $\mathrm{~h}$ \\
\hline ش & sy & $s$ & ' \\
\hline ص & sh & ي & $y$ \\
\hline ض & $\mathrm{dl}$ & & \\
\hline
\end{tabular}

B. Madd dan Diftong

\begin{tabular}{|c|c|c|c|}
\hline Arab & Latin & Arab & Latin \\
\hline T & â (a panjang) & آوَ & aw \\
\hline اين & î (i panjang) & اَيْ & ay \\
\hline أو & û (u panjang) & & \\
\hline
\end{tabular}




\section{PETUNJUK BAGI PENULIS DE JURE}

1. Artikel yang ditulis untuk de Jure merupakan hasil penelitian dan hasil pemikiran di bidang syariah dan hukum yang belum pernah diterbitkan di media cetak lain.

2. Naskah diketik dengan huruf Times New Roman ukuran 12 pts dengan spasi 1.5 pts, dan dicetak pada kertas A4 sepanjang 20-25 halaman dan diserahkan dalam bentuk cetak (hard copy) sebanyak 1 eksemplar disertai file-nya dalam bentuk Microsoft Word tipe $r t f$. File tersebut dapat dikirim melalui attachment e-mail ke alamat: syariah@uin-malang. ac.id

3. Nama penulis dicantumkan tanpa gelar akademik disertai nama dan alamat lembaga, nomor telepon dan alamat e-mail aktif.

4. Seluruh naskah ditelaah secara anonim oleh mitra bestari (reviewer) yang ditunjuk oleh penyunting sesuai bidang kepakarannya. Penulis artikel diberi kesempatan untuk melakukan perbaikan naskah atas dasar rekomendasi dari mitra bestari (reviewer).

5. Bagi penulis yang artikelnya dimuat akan menerima jurnal sebanyak 2 eksemplar cetak lengkap dan 3 eksemplar cetak lepas. Artikel yang tidak dimuat tidak akan dikembalikan, kecuali atas permintaan penulisnya.

6. Sistematika penulisan artikel adalah sebagai berikut:

a. Hasil Penelitian: judul; nama penulis; nama lembaga; nomor telepon dan alamat email; abstrak berbahasa Indonesia dan Inggris (90-100 kata) yang berisi tujuan, metode dan hasil penelitian; pendahuluan (tanpa judul) yang berisi latar belakang; tinjauan singkat tentang pustaka dan tujuan penelitian; metode penelitian; hasil dan pembahasan; kesimpulan dan saran; daftar pustaka terpakai.

b. Hasil Pemikiran: judul; nama penulis; nama lembaga; nomor telepon dan alamat email; abstrak berbahasa Indonesia dan Inggris yang berisi pemadatan dari tujuan penulisan dan hasil pembahasan (90-100 kata); pendahuluan (tanpa judul) yang berisi latar belakang dan tujuan atau ruang lingkup tulisan; bahasan utama (pembahasan) dapat dibagi ke dalam beberapa sub-bahasan; kesimpulan; daftar pustaka terpakai.

7. Tatacara penulisan judul dan sub judul:

a. level pertama (Judul): menggunakan huruf kapital semua, cetak tebal dan ditulis di tengah.

b. level kedua: menggunakan huruf kapital di setiap awal kata, cetak tebal dan ditulis rata di sebelah kiri.

c. level ketiga: menggunakan huruf kapital di awal kalimat, cetak tebal dan ditulis rata di sebelah kiri.

8. Penomoran dalam kalimat atau dalam pembahasan ditulis langsung dalam paragraf dengan menggunakan angka di dalam kurung, contoh: (1), (2), (3) dan seterusnya, atau huruf alphabet kecil di dalam kurung, contoh: (a), (b), (c) dan seterusnya.

9. Semua tulisan menggunakan referensi model footnote. Berikut aturannya:

${ }^{1}$ Khaled Abou El Fadl, Speaking in God's Name Islamic Law, Authority and Women (Oxford: Oneworld Publications, 2003), h. 24.

${ }^{2}$ Yvonne Yazbeck Haddad \& Barbara Freyer Stowasser (eds), Islamic Law and the Challenges of Modernity (Oxford: Altamira Press, 2004), h. 47.

${ }^{3}$ Ibid., h. 50 
${ }^{4}$ El Fadl, Speaking..., h. 79

10. Sumber pustaka dianjurkan merupakan terbitan 10 tahun terakhir.

11. Daftar pustaka disusun mengikuti contoh berikut:

\section{a. Buku}

El Fadl, Khaled Abou. 2003. Speaking in God's Name Islamic Law, Authority and Women. Oxford: Oneworld Publications.

\section{b. Buku terjemahan}

Ahmad, Saiyad Fareed \& Ahmad, Saiyad Salahuddin. 2004. 5 Tantangan Abadi Terhadap Agama dan Jawaban Islam Terhadapnya. Terjemahan oleh Rudy Hariansyah Alam. 2008. Bandung: Mizan.

\section{c. Buku kumpulan artikel}

Haddad, Yvonne Yazbeck \& Stowasser, Barbara Freyer (eds). 2004. Islamic Law and the Challenges of Modernity. Oxford: Altamira Press.

\section{d. Artikel dalam buku kumpulan artikel}

Tohari, Muhammad. 2001. Syariat Islam dan Partai Politik. Dalam Kurniawan Zein \& Sarifuddin HA (eds), Syariat Islam Yes Syariat Islam No (h. 105-109). Jakarta: Paramadina.

\section{e. Artikel dalam jurnal atau majalah}

Muhtarom, Bayyinatul. 2007. Al-Qur'an dan Material Genetik dalam Sel Kelamin Pria Penentu Jenis Kelamin Bayi. Ulul Albab. Volume ke-8, Nomor 2: 57-61.

\section{f. Artikel dalam koran}

Kuncoro, Toha. 1 Desember 2007. Pergulatan Menuju Perdamaian Palestina. Jawa Pos: 6 (kolom 2-5).

\section{g. Tulisan berita dalam koran (tanpa penulis)}

Surya. 31 Desember 2008. KPK Pelototi Dana Yayasan Instansi Negara, hlm. 3.

h. Dokumen resmi

Pusat Pembinaan dan Pengembangan Bahasa. 1978. Pedoman Penulisan Laporan Penelitian. Jakarta: Depdikbud.

Undang-Undang Republik Indonesia Nomor 2 tentang Sistem Pendidikan Nasional. 1990. Jakarta: PT Armas Duta Jaya.

\section{i. Skripsi, tesis, disertasi, laporan penelitian}

Baharuddin, Rahmawati. 2000. Tesis tidak diterbitkan. The

Netherlands: Leiden University.

j. Makalah seminar, lokakarya, penataran, pelatihan, workshop

Rahardjo, Mudjia. 2007. Metodologi Penulisan Artikel Jurnal Ilmiah. Makalah disajikan dalam Workshop Pelatihan Mutu Jurnal Ilmiah, Unit Informasi dan Publikasi (Infopub) Universitas Islam Negeri (UIN) Malang, 7-12 Desember.

\section{k. Tulisan internet}

Hitchcok, S., Carr., L. \& Hall, W. 1996. A Survey of STM Online Jurnal, 1990-1995: The Calm Before the Storm, (Online), (http://journal.esc.soron.ac.ud/survey.html. Diakses 12 Juli 2008).

\section{Artikel dalam jurnal online}

Samsul Hadi. 2007. Filsafat Ikhwan as Shafa. Ulul Albab. (Online) Volume 8, No. 4, (http://www.uin-malang.ac.id. Diakses 17 Desemberr2008) with 